\title{
POLASTMA — the Polish National Programme of Early Diagnosis and Therapy of Asthma
}

\author{
POLASTMA — polski narodowy program wczesnej diagnostyki i terapii astmy
}

The authors declare no financial disclosure

\begin{abstract}
Asthma represents a growing health, social, and economic issue as it affects a considerable part of the population, adversely affecting patients' quality of life, while its chronic character and severity of symptoms impair family life. It has been estimated that $12 \%$ of the population of Poland ( 4.5 million) suffer from asthma and $16 \%$ report wheezes (5.7 million). In order to improve asthma care and patient outcomes, evidence-based recommendations must not only be developed, but also disseminated and implemented at a national and local level, which is key for integration into clinical practice. For these reasons, the Polish Society of Allergology (PSA) has decided to undertake actions, leading to some improvement of the epidemiological situation in Poland. The Polish National Programme of Early Diagnosis and Therapy of Asthma has been developed. This initiative is a response to the demand for medical care improvement in patients with asthma. Its goals include early diagnosis of asthma and improved control in the course of the disease, a reduction in the number of subjects with asthma-associated disability for work, an increased use of anti-inflammatory agents vs. rescue medications, a reduced number of patients with severe, uncontrolled bronchial asthma and prevention of complications of the disease and of adverse effects of applied therapy, an increase in social awareness regarding the bulk of problems associated with asthma, and reduction of the total costs of the care of patients suffering from asthma. Details regarding programme assumptions, goals, target groups, and modes of implementation are described in the document.
\end{abstract}

Key words: bronchial asthma, action plan, early diagnostics, asthma therapy

Pneumonol. Alergol. Pol. 2014; 82: 597-607

\section{Streszczenie}

Astma oskrzelowa stanowi rosnący problem zdrowotny, społeczny i ekonomiczny. Choroba ta w istotny sposób wpływa na jakość życia pacjenta, ze względu na przewlekły przebieg i nasilenie objawów upośledza aktywność i życie rodzinne. Badania epidemiologiczne wykazały, że w Polsce na astmę cierpi około 12\% populacji (4,5 miliona osób), a 16\% populacji (5,7 miliona) zglasza świsty. W celu poprawy jakości opieki nad pacjentami nalezy nie tylko tworzyć zalecenia oparte na wynikach najnowszych badań, ale również dbać o rozpowszechnienie i implementację nowych standardów w codziennej praktyce. Z tego powodu Polskie Towarzystwo Alergologiczne (PTA) wystąpiło z inicjatywą opracowania Polskiego Narodowego Programu Wczesnej Diagnostyki i Terapii Astmy. Inicjatywa ta jest odpowiedzią na potrzebę poprawy jakości opieki medycznej nad pacjentami z astmą. Cele Programu obejmują wczesne rozpoznanie choroby, poprawę kontroli astmy, spadek liczby dni niezdolności do pracy z powodu astmy, wzrost stosowania leków kontrolujących w stosunku do leków ratunkowych, spadek liczby pacjentów z ciężką, trudną do leczenia postacią astmy, spadek powikłań wynikających z potencjalnych efektów ubocznych terapii, wzrost świadomości społecznej problemu astmy, a w konsekwencji spadek kosztów opieki nad pacjentami z astmą. Poniższe opracowanie przedstawia szczegóty założeń Programu, jego cele, grupy docelowe i metody działania.

Słowa kluczowe: astma oskrzelowa, plan działania, wczesna diagnostyka, terapia astmy

Pneumonol. Alergol. Pol. 2014; 82: 597-607

Address for correpondence: Prof. Piotr Kuna, MD, PhD, USK im. N. Barlickiego, UM w Łodzi, ul. Kopcińskiego 22, 90-153 Łódź, tel.: +48 42 677 67 77, e-mail: piotr.kuna@umed.lodz.pl DOI: 10.5603/PiAP.2014.0079

Praca wpłynęła do Redakcji: 26.05.2014 r.

Copyright (C) 2014 PTChP

ISSN 0867-7077 


\section{Asthma as a global health, social, and economic issue}

The number of patients suffering from asthma has doubled during the last ten years. The World Health Organisation (WHO) assumes that 300 million people all over the world are now affected by this disease, while the incidence of asthma will continue to rise, involving a further 100 million patients by the year 2025 [1]. In Europe this disease affects 30 million people, amounting for as much as $40 \%$ of subjects in certain populations [2]. The growth of asthma incidence has changed its meaning in the hierarchy of social health demands. At present, asthma is perceived in many countries as a serious health, social, and economic issue as it affects a considerable part of the population, adversely affecting people's quality of life, while its chronic character and severity of symptoms impair family life and constrain the professional and social activity of affected patients [3, 4]. Thus, asthma is, in certain countries, the most frequent cause of disability in work and is the most frequent chronic disease in children and the most common reason for their absence from school. Asthma also quite often requires therapy in a hospital environment. The WHO estimates that every year 25 million disability-adjusted life years (DALYs) are lost because of asthma. Every year, 255 thousand people die from asthma [1], i.e. one per all 250 deaths in the world results from asthma. In Europe, one man dies from asthma every hour, and $90 \%$ of these death cases could have been prevented by having improved medical care and reducing exposure to risk factors [2].

The annual asthma-related costs in the European Union amount to approximately EURO 17.7 billion, while the loss of production capacity, resulting from poor asthma control, costs Europe EURO 9.8 billion per year [2]. Finnish studies have demonstrated that the treatment of patients suffering from severe asthma is 13 times more expensive than in the mild course of this disease [5]. Therefore, the expenses born with regard to the treatment of patients with severe asthma, i.e. $20 \%$ of the total number of patients suffering from this disease, consumed $60 \%$ of all the funds allocated for asthma therapy. These figures result from high costs of hospitalisation. In the USA, they stand for as much as $51.2 \%$ of the direct costs of asthma therapy, $10.5 \%$ referring to first-aid, $18.4 \%$ reflecting the costs of outpatient therapy, and $19.9 \%$ resulting from drug reimbursement [6]. Beside the direct costs of medical treatment, asth- ma is a cause of high economic (i.e. non-medical) costs, including those associated with the following: the loss of production capacities, sick leave, disability pensions, nursing benefits, etc. [7]. The indirect costs are much higher than the direct ones, although they are rarely considered in the general social awareness.

With regard to the alarming epidemiological situation, the Global Initiative for Asthma (GINA) has been established under the auspices of the WHO and NHLBI, gathering experts from all over the world [8]. The main task of this organisation was the development, and then continuous updating, of the guidelines for asthma diagnostics and therapy. The latest update of GINA (issued May 6, 2014) points out that in order to improve asthma care and patient outcomes, evidence-based recommendations must not only be developed, but also disseminated and implemented at a national and local level, which is key to integration into clinical practice. It has been noted that recommendations for implementing asthma strategies are based on successful programs worldwide, and that implementation requires an evidence-based strategy taking into account local cultural and socioeconomic conditions [8]. However, it appears from the studies performed in France [9] that, despite the existence of the guidelines, as many as $66-86 \%$ of patients with bronchial asthma are improperly treated: $62-84 \%$ of patients with severe asthma do not receive any anti-inflammatory agents. These patients are particularly exposed to recurring, severe exacerbations of asthma, often demanding hospital care. High sick-leave absence rates at work and school are observed in this group of patients, while the risk of death is also higher among these patients.

In the international AIRE study in 1999 [10], only $5.1 \%$ of adult respondents achieved the targets of effective asthma treatment as defined by GINA. Only $23 \%$ of the studied subjects used inhaled glucocorticosteroids, and only $41 \%$ of the respondents had used anti-inflammatory drugs during the last 4 weeks, while rescue drugs were used by $2 / 3$ of the studied population. If asthma is not properly controlled, it considerably limits the patient's life activity, significantly impairs the quality of life, and may also become a life-threatening condition. The defined and published standards of management, dedicated to persons suffering from asthma, will not be effective if they are not applied in everyday healthcare practice. Meanwhile, as it appears from performed studies, asthma is not properly diagnosed, phy- 
sicians improperly evaluate the required degree of asthma control and recommend inappropriate therapy, and patients do not know how to use their inhalers and do not adhere to medical recommendations. All of this leads to poor asthma control, disease progression to its severe forms, the necessity of frequent emergency interventions, frequent hospitalisations, life threatening attacks, and even deaths from asthma.

The epidemiological situation in Europe has become the subject of analysis performed by a group of experts from the Centre for European Policy Studies for the Asthma, Allergy, and Inflammation Research Group, appointed within the $6^{\text {th }}$ Framework Programme of the European Union. It recommends that EU Member States develop integrated programmes of asthma management. Such a plan [11] was earlier implemented in Finland, resulting in better accessibility to medical care, improved care of patients with asthma, earlier diagnosis of the disease, a decrease of the number of patients suffering from the severe forms of the disease, and, despite the increased number of patients, a reduction in the total costs of care by more effective control of the disease, allowing for much lower expenses for emergency conditions and patient disability consequences. Intensive works are underway to develop and implement similar plans in other countries of the European Union.

\section{Why do the Polish citizens need the programme?}

The problem of the rapid increase in the incidence of asthma and other allergic diseases was noted by the Polish Society of Allergology in the 1990s. At that time, the first national epidemiological study of the prevalence of atopic diseases in Poland (PMSEAD) was designed and undertaken [12]. The prevalence of bronchial asthma in Poland was estimated at the level of 8.6\% (95\% CI: 7.7-9.6) in children and 5.4\% (95\% CI: 5.0-5.8) in adult patients [13]. In 2005 ECAP, another national epidemiological study, was started, and the initial results confirmed a higher incidence of asthma in urban areas [14]. It has been found that allergies affect about $40 \%$ of Polish citizens (14.4 million inhabitants), with the most frequent being allergic rhinitis $(25 \%$, 9 million inhabitants) followed by asthma (12\%, 4.5 million inhabitants). Moreover, smoking has been identified as a serious social problem associated with allergic diseases [15]. Similarly, in the COPD cohort $57 \%$ of patients admitted current smoking and $43 \%$ declared smoking in the past. The negative impact of smoking on family relations was declared by $16.4 \%$ of respondents [16].

In Łódź, the highest incidence rates of asthma were found in the city-centre area, being 3-times higher than those in agricultural areas [17]. Moreover, the results of the study revealed shortcomings in the healthcare system. Forty-eight per cent of adult asthma sufferers had not used any antiasthma medication in the previous 12 months, and the most commonly used medications were beta(2) agonists (46.8\%), inhaled glucocorticosteroids $(36.4 \%)$, and xanthine derivatives (33.8\%). Insufficient control of asthma in patients is a problem in Poland. In the AIRCEE (Asthma Insights and Reality in Central and Eastern Europe) study published in 2004, evaluating the degree of disease control in patients suffering from asthma, more than $70 \%$ of respondents reported diurnal symptoms of bronchial asthma at least once a week, while $20 \%$ experienced them every day. Almost $18 \%$ of the studied subjects were hospitalised during the last year of the study, and almost half of them had to seek immediate medical care. Almost $50 \%$ of the patients received diastolic agents, and only $27 \%$ were treated with inhaled glucocorticosteroids [18]. In Poland, in 2006, there were approximately 58 thousand hospital admissions because of asthma, including 5 thousand cases with a direct threat to the patient's life because of status asthmaticus. The average required period of hospitalisation in cases of asthma is 8 days, extending to 12 days for status asthmaticus [19].

For these reasons, the Polish Society of Allergology has decided to undertake actions in an attempt to see some improvement in the epidemiological situation in Poland. The National Programme of Early Diagnostics and Therapy of Bronchial Asthma has been developed by the initiative of the PSA's President. This initiative is a response to the demand of medical care improvement in patients with asthma. Its goals include early diagnosis of asthma and improved control in the course of the disease, a reduction in the number of subjects with asthma-associated disability for work, increased use of anti-inflammatory agents vs. rescue medications, a reduced number of patients with severe, uncontrolled bronchial asthma, prevention of complications of the disease and of adverse effects of applied therapy, an increase in social awareness regarding the bulk of problems associated with asthma, and a reduction of the total costs of the care of patients suffering from asthma. 


\section{Programme assumptions and goals}

One of the most burning problems regarding the medical care of patients with bronchial asthma is the failure to diagnose the disease. The latest epidemiological studies indicate that, despite the international publications (GINA) and national standards of management, only approximately $30-40 \%$ of patients are property diagnosed. Underdiagnosis results in delayed implementation of effective treatment and, consequently, in the development of more severe forms of the disease, demanding a higher number of ambulance interventions and hospitalisations. The basic assumptions of the National Programme of Early Diagnostics and Therapy of Bronchial Asthma include an increased identification of bronchial asthma, both in children and in adults and, as a direct consequence of early diagnosis, conformity with standards and early administration of appropriate treatment protocols, including anti-inflammatory drugs (Tab. 1).

Early diagnostics and treatment will prevent the development of irreversible functional disorders of the respiratory system (asthma is the second greatest risk factor of developing chronic obstructive lung disease, after exposure to tobacco smoke), will reduce the number of severe cases of the disease, including mortal ones, reduce the number of disability pensions that result from asthma, and will reduce the costs of care applied to patients with bronchial asthma. The goal of the Programme is not a design of any new standards of management but a general improvement of the medical care of asthmatic patients with a decrease of its costs by implementation of the actual recommendations in everyday practice, based on scientific evidence, international recommendations, and national groups of experts. This Program is part of the Global Alliance against Chronic Respiratory Disorders (GARD), an international strategy implemented under the protectorate of the World Health Organisation (WHO). The Programme has been dedicated to GPs and will be performed along the guidelines of the Practical Approach to Lung Health (PAL) strategy.

\section{Target groups}

Implementation of the programme will involve all the persons who participate in the care of asthmatic patient as well as those having contact with the patients. In particular, the programme is dedicated to primary care physicians and paediatricians. Nurses and pharmacists
Table 1. Basic assumptions of the Programme of Early Diagnostics and Therapy of Bronchial Asthma in Poland

Goals of the National Programme of Early Diagnostics and Therapy of Asthma

1. Early diagnosis of asthma

2. Better pharmacological control:

a. reduced number of hospitalisation days because of asthma

b. decreased mortality rates because of asthma

c. reduced number of persons with asthma-related disability for work

increased use of anti-inflammatory vs. symptomatic drugs

3. Reduced number of patients with severe, uncontrolled

bronchial asthma

4. Prevention of disease complications and adverse effects of therapy

5. Higher social awareness regarding the problems associated with asthma

6. Reduction of the total costs of care of patients with asthma

should also be involved in the active care and education, as they may increase the effectiveness of the therapy by education and control of patients' compliance with recommendations. In time, the programme is to be extended to other physicians/specialists who have contact with asthmatic patients. It is also important to strengthen the role of these specialists as experts in the diagnostics and therapy of patients suffering from asthma.

\section{Primary care physicians (PCPs)}

Early suspicion of bronchial asthma and consideration whether further diagnostics is appropriate and justified are the dilemmas of a primary care physician and not of a specialist in a clinical environment. For this reason, PCP is the main target group for the programme, to which educational activities are dedicated. The assumption of the programme is increased identification of asthma and the earliest possible administration of proper treatment. Properly trained primary care physicians (PCPs), familiar with the standards of therapeutic management, should have an opportunity to diagnose asthma at reference diagnostics centres. Diagnostic specialist centres ensure high and repeatable quality of tests and studies. The medical care of milder forms of bronchial asthma should be left to the management of PCPs. Any doubtful cases, severe forms of bronchial asthma, hypersensitivity to drugs, or therapeutic failures should be referred by PCPs to specialist outpatient clinics. This will decrease the costs of care of asthmatic patients. 


\section{Paediatricians}

Diagnosis of bronchial asthma in children is a difficult task, especially in the youngest age groups, where viral infections with obturation are frequently observed. Therefore, the advising of education in this group of physicians is clear and unquestionable.

\section{Nurses}

The basis for effective care of patients suffering from chronic diseases is regular education and the control of adherence to physician's recommendations. The role and potentials of nurses are now rather underestimated in Poland. The tasks of properly trained nurses may include patient education concerning the proper use of inhalation drugs, peak-flow meter operations, and training in recommended procedures in case of disease exacerbation, following individual management protocols that should have been earlier designed with the physician.

\section{Pharmacists}

A significant practical problem in the care of patients with bronchial asthma concerns errors in the use of inhalation drugs, the effect being limited efficacy of the applied therapy. The main educational task for the pharmacists will be the promotion of the proper use of drugs administered via inhalers. Additionally, they could control the proportions of administered symptomatic and disease-controlling drugs, as well as promoting simple tests evaluating the actual degree of asthma control, basic measurements of the respiratory system efficiency (PEF, peak expiration flow), plans of management in cases of disease exacerbations, and encouraging sufferers to visit a doctor when necessary (including cases of increased use of rescue drugs).

\section{Obstetricians}

A problem often faced in our everyday practice is insufficient knowledge regarding the safety of drug usage in pregnant women, also those with bronchial asthma. Sometimes, all inhalation drugs are withdrawn, leading to asthma exacerbations and significant complications. The goal of the programme is to provide obstetricians with the necessary knowledge on the safety of anti-asthmatic drugs in gestation.

\section{Patients with asthma and society}

Basic information concerning bronchial asthma should be provided to affected patients, as well as distributed in the whole of society.
Educational activities should be developed in close cooperation and as an answer to goals identified by patients' organisations. One of the goals of the Programme should be the effective elimination of the stigmatisation of patients with diagnosed asthma. An important message is such that bronchial asthma is, in fact, a chronic disease, but proper adherence to prescribed therapy usually ensures effective control of asthmatic symptoms. Among patients with the diagnosed disease, education is very important, concerning the necessity of regular use of recommended drugs, the way of application of inhalation drugs, and the propagation of recommended procedures in cases of exacerbation. It is advisable to provide information concerning the safety of inhalatory glucocorticosteroids, as steroidophobia is a significant problem in everyday practice and may be responsible for worse patient compliance with physicians' recommendations. Some information about asthmatic symptoms, targeted towards groups at increased risk, especially to allergic patients and patients with allergic rhinitis, will result in better detectability of the disease.

\section{The role of specialists}

Local specialist centres will be the main link in the educational network, which will be the base for the programme. Because of the scale of the programme in Poland, the first training sessions, propagating the programme ideas, will be held at the largest units in academic centres and big cities. They should provide the base for reference diagnostic centres (minimal basic diagnostics includes spirometry, provocation tests, and skin tests) to be available for patients referred by PCPs. In subsequent stages these centres will become the framework for local training networks dedicated to PCPs. The division of tasks of PCPs and specialists in the care of patients with bronchial asthma will be developed in collaboration between specialists and PCPs in one of the appointed working groups.

\section{Activity areas}

The programme has been addressed to society and to the medical environment; therefore, the activities have been configured on these planes. In order to ensure the programme's effective implementation, the involved organisational units will enter collaboration with medical environments, patient environments, media, governmental, and non-governmental organisations. 
Table 2. Chief action methods within the National Programme of Early Diagnostics and Therapy of Bronchial Asthma

Chief action methods within the National Programme of Diagnostics and Therapy of Bronchial Asthma

1. Promotion of diagnostic and therapeutic management, in adherence with standards based on scientific evidence

2. Extension of educational networks based on local specialist centres

3. Training coverage of key target groups: PCPs, paediatricians, nurses, pharmacists, obstetricians

4. Educational coverage of patients and of the whole of society

5. Unification of diagnostic methods, creation of local diagnostic reference centres, available for PCPs

6. Promotion of therapy of disease exacerbations, based on individual management plans

7. Education in the proper use of inhalation drugs

8. Promotion of healthy lifestyles, including the fight with tobacco smoking addiction

9. Promotion of research on bronchial asthma

The main tasks of the programme include propagation of basic knowledge on asthma in society and intensive training sessions of physicians to improve their qualifications and, consequently, the quality of care provided to patients with asthma. The programme is dedicated directly to society and to physicians, but first of all to primary care physicians (PCPs). Education is to be at the base of all the undertaken actions. Training sessions and events will be held by specialists who provide care to patients suffering from asthma. The organisation of regional specialist centres for the care of patients with asthma is to facilitate a closer collaboration between PCPs and specialists in allergology and pulmonology. It will also provide assistance to other specialists, to whom asthmatic patients are referred with other health problems.

Active collaboration will be undertaken with the National Healthcare Fund regarding the implementation of changes in the actual healthcare system, to improve the care of asthmatic patients and to more effectively utilise the funds allocated for this purpose.

\section{Programme implementation tools}

The implementation of guidelines concerning the diagnostics and therapy of asthma requires application of appropriate means (Tab. 2). The basis for the implementation shall be a series (2-3) of short (approximately 2-hours) training sessions delivered either on-site at the location of the audience's work or at the reference centres for small groups of participants. Other forms of knowledge promotion and distribution will include symposia and conferences devoted to the programme, or dedicated sessions during other conferences of societies/associations of doctors, nurses, midwives, and pharmacists. Oral presentations require printed and audio-visual aids to be better understood and remembered. Necessary materials will be prepared for each target group, taking into account their specific character and range of activities.

\section{Programme structure}

The programme is being developed under the auspices of the Polish Society of Allergology (PSA) by the initiative of the PSA's President, who, together with other authors, brought up the initial idea of the programme. The PSA's President, following positive results of the programme review, will appoint the Programme Council, consisting of:

- Executive Committee,

- Research Council,

- Council for Evaluation of the Programme Implementation.

The Commission for Evaluation of the Programme Implementation shall be appointed by the Board of the Polish Society of Allergology as an organ independent of the Executive Committee. Its tasks shall include:

- evaluation of the effectiveness of the Programme implementation,

- evaluation of the Programme outcomes,

- advisory role towards the Executive Committee and the Working Groups of the Executive Committee.

For details regarding the programme structure see Figure 1.

\section{Programme goals — modes of accomplishment}

The ways to accomplish the goal of early asthma diagnosis are presented in Table 3. In order to see information about detailed modes of action to improve asthma control, reducing the number of patients with poor asthma control, educating patients in proper inhalation techniques, reducing the number of patients with severe, uncontrolled asthma, preventing disease complications and side effects of therapy, increasing awareness of the problems associated with asthma among society and policy makers, reducing the costs of asthma care, please see the full version of the POLASTMA programme available online ( $w w w$.mojaastma. org.pl or www.pta.med.pl). 


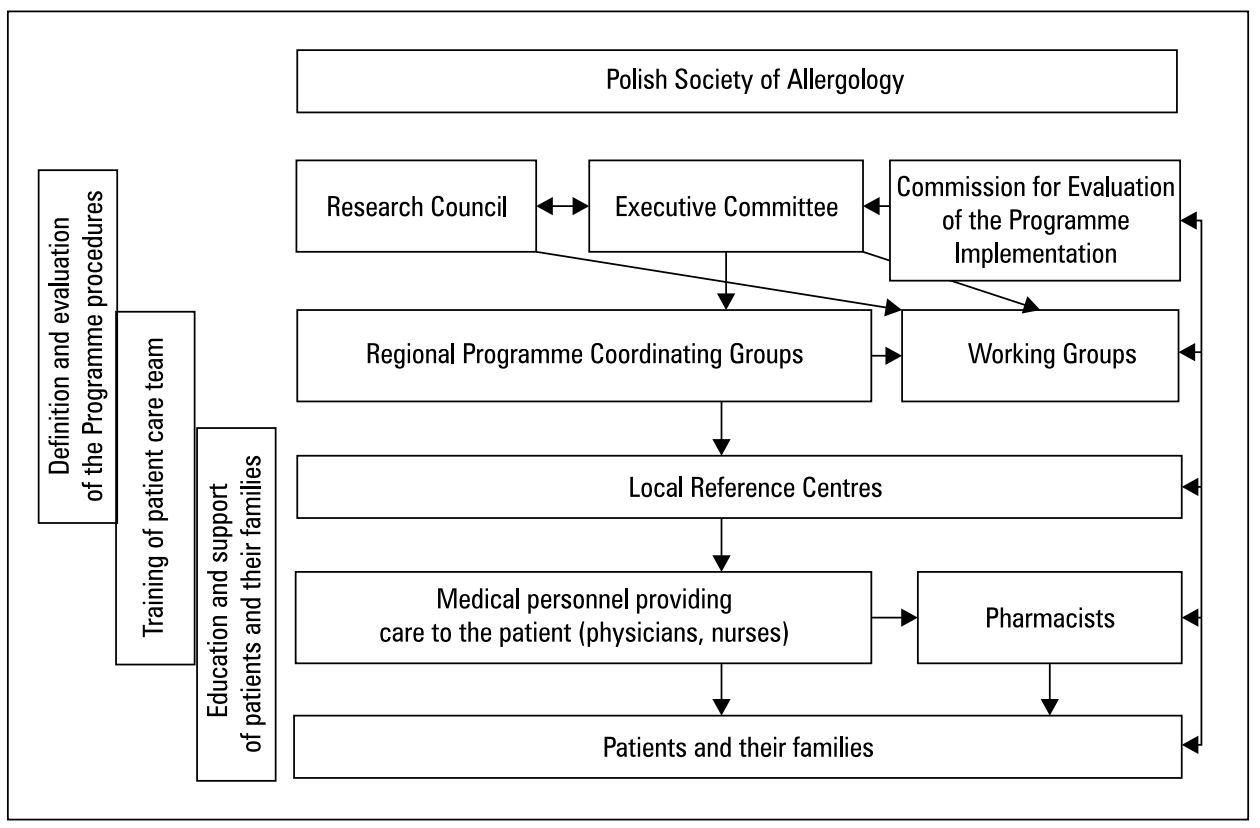

Figure 1. Operational structure of the Polish National Programme of Early Diagnosis and Therapy of Asthma (POLASTMA)

Table 3. Ways to accomplish the goal of early asthma diagnosis

\section{Early asthma diagnosis}

\section{Tasks:}

1. Improvement of early asthma diagnosis at the primary care level

2. Distribution of general information on asthma among physicians of other specialties

3. Distribution of general information on asthma in broad society

Activities:

1. Education of primary care physicians

2. Design of the bronchial asthma diagnostic algorithm for PCPs

3. Extension of the range of tasks of PCPs, regarding diagnostics

4. Increasing the availability of spirometric and allergological tests for PCPs

5. Preparation of press releases on asthma for social needs and active involvement in its propagation in the mass media

6. Support of patient organisations in propagating knowledge about asthma

7. National social actions, e.g. organisation of World Asthma Day

Tools:

1. Training sessions for physicians concerning asthma diagnostics (including the interpretation of spirometric tests)

2. Symposia and conferences devoted to diagnostic problems in asthma

3. Brochures

4. Algorithms of asthma diagnostics developed for the needs of primary care

5. Training of nurses in spirometric tests

\section{Programme implementation assessment}

A precisely scheduled and repeated evaluation of particular training sessions/events at the local le- vel will be the basis for the assessment of efficiency of all the actions undertaken within the programme. In subsequent years, an evaluation of the final programme stages will be absolutely crucial.

\section{Evaluation of programme development and training efficacy}

Every training session/event should be preceded by a short test, checking the knowledge of participants regarding the discussed issues. The same test should be repeated after training. The test results should be sent to participants and filed at the Programme Office for further analysis. After each training session, the participants should be given the possibility to evaluate the quality of training, lecturers, and materials and to propose new subjects that are important for their everyday practice.

\section{Evaluation of the programme results in subsequent years}

It will be necessary for correct evaluation of the programme results in order to create a database with data describing selected parameters at their initial stage, followed by an evaluation of these parameters in subsequent years of the programme's duration. It will be necessary to start collaboration with organisations that are involved in the acquisition of data necessary for programme evaluation and to obtain access to the required data. Evaluation of the programme 
Table 4. Executive summary of POLASTMA — the National Programme of Early Diagnostics and Therapy of Asthma

\begin{tabular}{|c|c|}
\hline $\begin{array}{l}\text { Knowledge } \\
\text { about asthma }\end{array}$ & $\begin{array}{l}\text { 1. Asthma as a civilisation disease - often diagnosed in developed countries, while its incidence rapidly grows in develo- } \\
\text { ping countries as well } \\
\text { 2. Patient care costs have been growing } \\
\text { 3. Evidence for inflammatory background of the disease } \\
\text { 4. State-of-the-art therapy ensures proper control of the disease }\end{array}$ \\
\hline $\begin{array}{l}\text { National } \\
\text { problems }\end{array}$ & $\begin{array}{l}\text { 1. Asthma in Poland occurs in } 10 \% \text { of children and } 6 \% \text { of adults } \\
\text { 2. It is often an unidentifiable disease - even as many as } 70 \% \text { of affected children are not properly diagnosed and, } \\
\text { consequently, not property treated } \\
\text { 3. Symptomatic drugs are overused in the therapy of asthma, while anti-inflammatory agents of disease suppressing } \\
\text { character are taken too rarely } \\
\text { 4. Asthma is a frequent cause of absence at work and school and is at the basis of high disability rates } \\
\text { 5. Untreated or poorly treated asthma leads to the development of chronic obturative lung disease } \\
\text { 6. Asthma is perceived as a disease that impairs normal life (an obstacle in normal life) }\end{array}$ \\
\hline Strategy & $\begin{array}{l}\text { 1. Making the persons who are responsible for healthcare policy aware that asthma in Poland is a serious health, social, } \\
\text { and economic problem } \\
\text { 2. Design and implementation of the National Programme of Early Diagnostics and Therapy of Asthma, oriented towards: } \\
\text { a) prevention of asthma } \\
\text { b) early diagnostics } \\
\text { c) therapy adjusted to actual patent needs } \\
\text { d) improved care of patients with severe, difficult-to-treat asthma } \\
\text { e) restoring the ability of affected patients to take part in school activities or work } \\
\text { f) prevention of disease complications and of therapy side effects } \\
\text { g) popularisation of knowledge on asthma in society }\end{array}$ \\
\hline Goals & $\begin{array}{l}\text { 1. Early diagnosis of asthma } \\
\text { 2. More effective pharmacological control: } \\
\text { a) to reduce the number of hospitalisation days because of asthma } \\
\text { b) to reduce the mortality rates because of asthma } \\
\text { c) to reduce the number of persons disabled from work by asthma } \\
\text { d) to increase the use of anti-inflammatory drugs vs. symptomatic drugs } \\
\text { 3. To reduce the number of patients with severe, uncontrolled bronchial asthma } \\
\text { 4. Prevention of disease complications and of therapy side effects } \\
\text { 5. To increase social awareness regarding the problems associated with asthma } \\
\text { 6. To reduce the total costs of care of asthmatic patients }\end{array}$ \\
\hline Tasks & $\begin{array}{l}\text { 1. To increase the awareness among physicians of the inflammatory background of asthma and to propagate } \\
\text { anti-inflammatory therapy } \\
\text { 2. Development of a bronchial asthma diagnostic algorithm for primary care physicians } \\
\text { 3. Development of simple guidelines for the therapy of asthma and its exacerbations } \\
\text { 4. Extension of tasks of PCPs, regarding the diagnostics and therapy of asthma } \\
\text { 5. Propagation of simple asthma control tools } \\
\text { 6. To increase the availability of spirometric and allergological tests for pcps } \\
\text { 7. To create a system of interdisciplinary care of asthmatic patients (including the care of pregnant women with asthma) } \\
\text { 8. To define standards of care for patients with severe, difficult-to-treat asthma } \\
\text { 9. To develop rehabilitation programmes, restoring the ability to work } \\
\text { 10. To define and extend the role of nurses in the care of patients suffering from asthma } \\
\text { 11. To increase the patient's role in the therapeutic process } \\
\text { 12. Patient education at each stage of contact with medical personnel, including pharmacists }\end{array}$ \\
\hline Activities & $\begin{array}{l}\text { Implementation of guidelines concerning the diagnostics and therapy of asthma at the primary care level } \\
\text { Updating the guidelines based on new reports and changes in the healthcare system in Poland } \\
\text { Preparation of lists of reference centres for primary care units in a given region } \\
\text { Coverage with specialist care of patients with severe, difficult-to-treat asthma } \\
\text { Moderating the collaboration between primary care units and specialist centres } \\
\text { Collaboration with other specialists, regarding the improvement of care of asthmatic patients } \\
\text { Preparation and distribution of informative and educational materials } \\
\text { Organisation of training events, symposia, and conferences devoted to the diagnostics and therapy of asthma } \\
\text { and presenting the programme's results } \\
\text { Preparation and support of legislative proposals, building the health-promoting policy of the state, e.g. smoking prohibition } \\
\text { in public areas } \\
\text { Collaboration with the National Healthcare Fund regarding the improved care of patients suffering from asthma } \\
\text { Collaboration with the Social Insurance Institution and Employment Agencies, regarding the professional activation } \\
\text { of asthmatic patients } \\
\text { Support of patient organisations in the education of patients } \\
\text { Collaboration with media, regarding the popularisation of knowledge on asthma }\end{array}$ \\
\hline
\end{tabular}


results will be performed by the independent Council of Programme Course Evaluation, grouping experts in epidemiological studies, social, and environmental medicine, statisticians, and specialists involved in the care of asthmatic patients.

\section{Pharmacoeconomic evaluation}

Evaluation of the programme results also includes pharmacoeconomic parameters with direct and indirect costs of the care of patients with bronchial asthma. In particular, the expenses will be accounted associated with disability pensions, doctor visits, hospital care, and drugs. The proportions of expenses in subsequent years will be assessed, with changes in the number of patients and the degree of the disease severity.

\section{Paediatric programme}

Asthma in children has a different course and prognoses than asthma in adult patients. Poor asthma control is not only a direct threat to health and life but it also negatively affects the child's development - physical, motor, psychic, and intellectual. Asthma is the most frequent chronic disease in children and the most frequent cause of their absence at school. Children are much more at risk from the side effects of used drugs than are adult subjects. Undiagnosed asthma in childhood or its unsatisfactory treatment leads to the development of severe, therapy-resistant asthma in adulthood.

Consequently, it is necessary to develop a separate paediatric programme within the national programme, dedicated to this group of patients. In the care of children suffering from asthma different problems are faced than those observed in the care of asthmatic adults. Children are often not self-reliant and their treatment requires collaboration with parents; therefore, the whole family should be involved in the therapeutic process. The proper use of inhalation drugs by older children is a big problem; therefore, appropriate education action should be undertaken, targeted both to children and to those adults who control the therapy. Another issue is the adherence of teenagers to the physician's recommendations, which is the worst among this particular age group. Asthmatic children often avoid physical exercise for fear of disease symptoms. They are exempted from physical training classes, which results in their weaker motor development. Therefore, actions should be undertaken optimising the therapy, while also allowing these children to partake in physical exercise.

\section{Severe, difficult-to-treat asthma}

Severe, difficult-to-treat asthma is the form of the disease that is most rare; however, it is burdened with the most serious complications and worst prognosis. Patients who suffer from severe/treatment resistant asthma:

- have low quality of life because of frequent symptoms and unexpected exacerbations of asthma,

- have limited life activity, they are often unable to perform their work,

- are particularly exposed to serious adverse effects of drugs, especially glucocorticosteroids,

- very often have coexistent diseases, such as gastroesophageal reflux and nasal sinusitis.

In the group of patients with the most severe forms of asthma, the following observations were made:

- they have the highest frequency of hospitalisations and visits at hospital emergency departments,

- they are at the highest risk level of asthma attacks leading to death.

The annual cost of therapy of a patient with severe asthma is several times higher than in case of a patient with a mild course of asthma. Therefore, these patients require specialist care and access to new therapeutic protocols. Such patients should obtain complex medical care at specialised centres. Complex care of patients suffering from severe asthma is at the base of the proper approach to these patients, who often demonstrate other, coexisting diseases, and the effective treatment of these diseases is a condition for general health improvement in the patients. These patients are submitted to surgical interventions for various indications, to which they should be properly prepared, and the drugs used by these patients for reasons other than asthma may also bias the course of asthma. Therefore, collaboration among physicians of various branches is also important in the management of these patients. In the care of these patients, one should not forget their psychological problems, troubles with work performance, and frequent sense of isolation from society because of their asthma-related disability.

\section{Programme assumptions for nurses}

A properly trained nurse plays an important role in the therapy of patient and helps attain asthma control. Regarding the physician's work, 
the nurse provides invaluable assistance in the care of the patient, both at the level of primary care in an outpatient clinic or at specialist unit. Prior to visiting the doctor, the nurse may evaluate the degree of asthma control by means of simple tests. The nurse may also recommend an additional control visit when worse parameters are found or may even recommend only the continuation of therapy. It is especially important in the practice of primary care physicians, where patients very often leave a request for drug continuation without having seen the doctor for several months. Another stage should comprise patient education, covering the issues concerning bronchial asthma, the adherence to individual treatment programmes, and the management of exacerbation cases, as determined earlier by the physician, as well as continuous training regarding the inhalation of drugs.

\section{Programme promotion}

This programme has been designed to improve the identifiability of asthma in the early stage of disease development and to improve the care of patients suffering from asthma. In order to obtain these goals the programme will have to be accepted by society for which it has been created, and by the medical environment in which it plays a key role. Therefore, the programme promoting activities will be addressed to broad social groups and to the medical environment. Information will be sent to many people, regarding the needs of prophylactics, early diagnosis, and modes of therapy, with a particular emphasis on the need for proper disease control.

In turn, doctors, nurses, and pharmacists will receive information about the epidemiological situation in Poland, the advantages of implementation of the programme and specialist knowledge concerning the care of asthmatic patients, specifying their needs. The information about the epidemiological situation and needs, and regarding the care of asthmatic patients, will be provided to the persons who decide about health care policy at the national level. For the sake of programme promotion, collaboration with the media will be undertaken. The applied tools will include brochures, releases in everyday press and in popular weeklies and monthlies, as well as in specialist journals, interviews, and radio and TV programmes. Social actions will also be undertaken to encourage society to take advantage of control examinations, promoting healthy lifestyles and health-improving activities.
Meetings of experts will also be held regarding the care of patients suffering from asthma, and of persons professionally involved in the national healthcare policy.

\section{Summary}

The executive summary of the programme is presented in Table 4. From the public health perspective it is a key issue to implement the best available standards of care in everyday practice. The asthma burden can be reduced using varied strategies, which can be achieved by local efforts, systematic planning, and networking to implement the best asthma care [20]. The programme is in line with the priorities of the Polish Presidency of the Council of the European Union, with the main goal to reduce health inequalities across societies and to prevent and control respiratory diseases in children, adolescents, and adults [21].

\section{Conflict of interest}

The authors declare no conflict of interest.

\section{References:}

1. www.who.int

2. www.ceps.eu

3. http://isaac.auckland.ac.nz

4. Kupryś I., Kuna P. Epidemia chorób alergicznych - nowy problem zdrowotny współczesnego świata (Epidemics of allergic diseases - a new health problem of today's World). Pol. Merkur. Lek. 2003; 14: 453-455.

5. Report of a Working Group. Asthma Program in Finland 19942004. Clin. Exp. Allergy 1996; 26: 1-24.

6. Lozano P., Sullivan S.D., Smith H.D, Weiss K.B. The economic burden of asthma in US children: Estimates from the National Medical Expenditure Survey. J. Allergy Clin. Immunol. 1999; 104: 957-963.

7. European Allergy White Paper. Allergic diseases as a public health problem in Europe. D. Van Moerbeke (red.). The UCB Institute of Allergy, Brussels 1997.

8. www.ginasthma.com

9. Bousquet J., Knani J., Henry Ch. et al. Undertreatment in nonselected population of adult patients with asthma. J. Allergy Clin. Immunol. 1996; 98: 514-521.

10. Rabe K.F., Vermeire P.A., Soriano J.B., Maier W.C. Clinical management of asthma in 1999: the Asthma Insights and Reality in Europe (AIRE) study. Eur. Respir. J. 2000; 16: 802-807.

11. Haahtela T., Tuomisto L.E., Pietinalho A. et al. A 10 year asthma programme in Finland: major change for the better. Thorax 2006; 61: 663-670.

12. Małolepszy J., Liebhart J., Wojtyniak B., Pisiewicz K., Płusa T. Występowanie chorób alergicznych w Polsce (Prevalence of allergic diseases in Poland). Alergia Astma Immunologia, VII Zjazd PTA (Allergy, Asthma, Immunology, The 7th Conference of the Polish Society of Allergology), Łódź 2000; S2: 163-169.

13. Liebhart J., Malolepszy J., Wojtyniak B., Pisiewicz K., Plusa T., Gladysz U.; Polish Multicentre Study of Epidemiology of Allergic Diseases. Prevalence and risk factors for asthma in Poland: results from the PMSEAD study. J. Investig. Allergol. Clin. Immunol. 2007; 17: 367-374.

14. Samoliński B. Epidemiologia alergii i astmy w Polsce - doniesienie wstępne badania ECAP (Epidemiology of allergy and 
asthma in Poland - a preliminary report of the ECAP study). Terapia 2008; 4: 127-131.

15. Stankiewicz-Choroszucha B.L., Wawrzyniak Z.M., Lipiec A. et al. Consequences of smoke inhalation in the "Epidemiology of Allergic Diseases in Poland” project (ECAP). Ann. Agric. Environ. Med. 2011; 18: 420-428.

16. Kupryś-Lipińska I., Kuna P. Impact of chronic obstructive pulmonary disease (COPD) on patient's life and his family. Pneumonol. Alergol. Pol. 2014; 82: 82-95.

17. Kupryś I., Elgalal A., Kuna P. The underdiagnosis and undertreatment of asthma in general population of the Lodz Province (Poland). Pneumonol. Alergol. Pol. 2010; 78: 21-27.

18. Kowalski M.L., Jędrzejczak M., Cirlić M. Efektywność leczenia astmy oskrzelowej w Polsce w ocenie pacjentów - wyniki badania AIRCEE (The efficacy of bronchial asthma therapy in
Poland in the estimation of the patients themselves - results of the AIRCEE study) (Asthma Insights \& Reality in Central and Eastern Europe). Alergia Astma Immunologia 2004; 9: 187-195.

19. Stelmach W., Majak P., Jerzyńska J., Stelmach I. Early effects of Asthma Prevention Program on asthma diagnosis and hospitalization in urban population of Poland. Allergy 2005; 60: 606-610.

20. Kupczyk M., Haahtela T., Cruz A.A., Kuna P. Reduction of asthma burden is possible through National Asthma Plans. Allergy 2010; 65: 415-419.

21. Samoliński B., Fronczak A., Kuna P. et al. Prevention and control of childhood asthma and allergy in the EU from the public health point of view: Polish Presidency of the European Union. Allergy 2012; 67: 726-731. 